\title{
Bacillus okhensis sp. nov., a halotolerant and alkalitolerant bacterium from an Indian saltpan
}

\author{
Correspondence \\ B. K. C. Patel \\ b.patel@griffith.edu.au
}

\author{
Bianca Nowlan, ${ }^{1}$ Mital S. Dodia, ${ }^{2}$ Satya P. Singh ${ }^{2}$ and B. K. C. Patel ${ }^{1}$ \\ ${ }^{1}$ Microbial Gene Research and Resources Facility, School of Biomolecular and Biomedical \\ Sciences, Griffith University, Brisbane, Australia 4111 \\ ${ }^{2}$ Department of Biosciences, Saurashtra University, Rajkot, India 360005
}

\begin{abstract}
A strictly aerobic, rod-shaped bacterium (0.6-0.8 $\times 2-3 \mu \mathrm{m})$, designated strain $\mathrm{Kh} 10-101^{\top}$, was isolated from a saltpan $\left(22^{\circ} 15^{\prime} \mathrm{N}, 69^{\circ} 1^{\prime} \mathrm{E}\right)$ in the vicinity of Port Okha, India. The creamish pigmented colonies of strain $\mathrm{Kh} 10-101^{\top}$ were round, flat and translucent with irregular margins and a smooth surface. The strain possessed up to three subpolar flagella, and was motile by a corkscrew motion. The strain grew optimally at $37^{\circ} \mathrm{C}$ (temperature growth range $25-40{ }^{\circ} \mathrm{C}$ ) in a complex glucose-containing medium with $5 \% \mathrm{NaCl}(\mathrm{NaCl}$ growth range $0-10 \%)$ at $\mathrm{pH} 9$ ( $\mathrm{pH}$ growth range $\mathrm{pH} \mathrm{7-10),} \mathrm{indicating} \mathrm{that} \mathrm{it} \mathrm{was} \mathrm{a} \mathrm{mesophilic} \mathrm{halotolerant} \mathrm{alkaliphile.} \mathrm{The} \mathrm{strain}$ was sensitive to lincomycin, meticillin, cefuroxime and cephalexin, but resistant to gentamicin, tetracycline and cotrimazine. Spores were not detected and cells were heat sensitive. The isolate metabolized a range of carbohydrates and hydrolysed casein, gelatin and starch. Growth was not observed on aromatic compounds, Tween 40 or Tween 80 . Nitrate was not reduced and catalase was produced. Electron microscopic examination of thin sections revealed a single thick Gram-positive cell wall. The DNA G +C content was $41 \pm 1 \mathrm{~mol} \%$. Phylogenetic analyses of the $16 \mathrm{~S}$ rRNA gene sequence revealed that strain $\mathrm{Kh} 10-101^{\top}$ was a member of the sixth rRNA group of the genus Bacillus, which includes alkalitolerant, alkaliphilic and halotolerant species. The halotolerant obligate alkaliphile Bacillus krulwichiae is the closest relative of strain Kh10-101 ${ }^{\top}$ (96\% similarity) but a number of phenotypic differences suggest that strain Kh10-101 ${ }^{\top}\left(=\mathrm{JCM} 13040^{\top}=\right.$ ATCC BAA-1137 $\left.{ }^{\top}\right)$ should be designated the type strain of a new species, for which the name Bacillus okhensis sp. nov. is proposed.
\end{abstract}

Haloalkaliphilic and alkalitolerant microbes occur naturally in alkaline and saline environments, and during the past decade, studies on the ecology, physiology and taxonomy of these organisms have revealed an impressive diversity. Haloalkaliphiles possess special adaptation mechanisms for survival under these two extremities. The members of the alkaliphilic and alkalitolerant Bacillus species form the sixth rRNA group (Nielsen et al., 1994) and have attracted much attention as they secrete extracellular enzymes that are both active and stable at high salt concentrations and high $\mathrm{pH}$. These properties make them an interesting tool for fundamental research and for biotechnological exploration (Margesin \& Schinner, 2001; Demirjian et al., 2001). The vast majority of haloalkaliphiles and alkalitolerant species have been isolated from athalassohaline environments (Duckworth et al., 1996; Jones et al., 1998; Pikuta et al., 2003; Rees et al., 2004) while thalassohaline environments have remained relatively less explored (Neilsen et al., 1995; Suzuki et al., 1997; Munoz et al., 2001; Amoozegar et al.,

The GenBank/EMBL/DDBJ accession number for the 16S rRNA gene sequence of strain $\mathrm{Kh} 10-101^{\top}$ is DQ026060.
2003). We describe in this report the characterization of a new halotolerant and alkalitolerant Bacillus species that was isolated from a thalassohaline environment.

A soil sample was collected from a natural saltpan near the shore of Port Okha $\left(22^{\circ} 15^{\prime} \mathrm{N}, 69^{\circ} 1^{\prime} \mathrm{E}\right)$ in sterile glass containers by scraping the soil surface. For initiating enrichment cultures, $1 \mathrm{~g}$ soil was diluted in $5 \mathrm{ml}$ sterile distilled $\mathrm{H}_{2} \mathrm{O}$, and large suspended solids were allowed to settle by gravitation for $10 \mathrm{~min}$, after which $1 \mathrm{ml}$ of the relatively clear suspension was added to a flask containing $100 \mathrm{ml}$ complex medium (CMB) consisting of $\left(\mathrm{g} \mathrm{l}^{-1}\right)$ : glucose, 10; peptone, 5; yeast extract, $5 ; \mathrm{KH}_{2} \mathrm{PO}_{4}, 5 ; \mathrm{NaCl}, 10-25 \%$. The medium was adjusted to $\mathrm{pH} 10 \cdot 0$ using sterile autoclaved $\mathrm{Na}_{2} \mathrm{CO}_{3}(20 \%$, w/v). CMB medium became turbid after $48 \mathrm{~h}$ incubation at $37^{\circ} \mathrm{C}$ and pure cultures were isolated by streaking $\mathrm{CMB}$ agar plates (CMB medium containing $2.5 \%$ agar). Single colonies that developed after 4 days incubation at $37^{\circ} \mathrm{C}$ on $\mathrm{CMB}$ plates were restreaked onto fresh $\mathrm{CMB}$ agar plates. The isolation procedure was repeated three times to obtain the pure culture. One of the pure cultures, Kh10$101^{\mathrm{T}}$, was designated a type strain, and characterized further. The pure culture was maintained on CMB medium $(\mathrm{pH}$ 9; 
$10 \%, \mathrm{w} / \mathrm{v}, \mathrm{NaCl}$ ) described above and stored at $4{ }^{\circ} \mathrm{C}$. The strain was subcultured at monthly intervals. Colonies of Kh10- $101^{\mathrm{T}}$ were round, flat and translucent with irregular margins, a smooth surface and a creamish pigment.

Cellular characterization and sporulation tests performed as described previously (Kanso \& Patel, 2003) showed that the cells of strain Kh10-101 ${ }^{\mathrm{T}}$ were rod-shaped $(0 \cdot 6-0 \cdot 8 \times 2-3 \mu \mathrm{m})$ and actively motile. Electron microscopy of negatively stained cells showed the presence of up to three subpolar flagella. The cells stained Gram-positive and thin sections revealed the presence of a typical thick Gram-positive cell wall. Microscopic examination did not reveal the presence of inclusion bodies or spores. The cells of strain Kh10-101 ${ }^{\mathrm{T}}$ were not viable after $10 \mathrm{~min}$ incubation at $70^{\circ} \mathrm{C}$, indicating the absence of heat-resistant bodies such as spores.

The optimal conditions for growth of strain Kh10-101 ${ }^{\mathrm{T}}$ were tested in a medium containing (per $100 \mathrm{ml}$ double-distilled $\mathrm{H}_{2} \mathrm{O}$ ): $1 \mathrm{~g}$ D-glucose, $0.5 \mathrm{~g} \mathrm{KH}_{2} \mathrm{PO}_{4}, 0.5 \mathrm{~g}$ peptone, $0.5 \mathrm{~g}$ yeast extract and $5 \mathrm{~g} \mathrm{NaCl}$. The strain grew optimally at $\mathrm{pH} 9$ (pH growth range $\mathrm{pH} 7-10)$ with $5 \% \mathrm{NaCl}(\mathrm{NaCl}$ growth range $0-10 \%$ ) at $37^{\circ} \mathrm{C}$ (temperature growth range $25-40{ }^{\circ} \mathrm{C}$ ). The generation time was determined to be $2.5 \mathrm{~h}$ under optimal growth conditions (CMB medium, $\mathrm{pH}$ 9, containing $5 \% \mathrm{NaCl}$ and incubation temperature of $\left.37^{\circ} \mathrm{C}\right)$.

To determine antibiotic sensitivity, an active culture of strain Kh10-101 ${ }^{\mathrm{T}}$ was inoculated onto CMB agar plates ( $\left.\mathrm{pH} 9\right)$ containing $10 \%(\mathrm{w} / \mathrm{v}) \mathrm{NaCl}$ following which Hi-media octadiscs impregnated with antibiotics were placed on their surface. The plates were incubated at $37^{\circ} \mathrm{C}$ for up to $48 \mathrm{~h}$ and the zones of inhibition around the antibiotic discs were recorded. Strain Kh10-101 ${ }^{\mathrm{T}}$ was found to be highly sensitive to lincomycin, meticillin, cefuroxime and cephalexin but resistant to gentamicin, tetracycline and cotrimazine.

Biolog GP2 plates (Hayward) were used to characterize the biochemical capacity of the strain using the manufacturer's recommended procedures but with the following modification. A culture of strain Kh10-101 ${ }^{\mathrm{T}}$ was centrifuged and the cell pellet was washed and resuspended in a tube of Inoculating Fluid (IF GN/GP) supplied with the Biolog plates, to which was added $1.25 \mathrm{~g} \mathrm{NaCl}$ and $1 \cdot 2 \mathrm{~g} \mathrm{Na}_{2} \mathrm{CO}_{3}$. The resulting fluid was filter-sterilized prior to use. Cell suspension $(150 \mu \mathrm{l})$ was then added to the wells of Biolog GP2 plates, and the plates were incubated at $37^{\circ} \mathrm{C}$ and read after $24 \mathrm{~h}$ as recommended by the manufacturer. Strain Kh10-101 ${ }^{\mathrm{T}}$ could metabolize 3-methyl glucose, D-fructose, D-fructose 6-phosphate, D-galactose, D-glucose, D-galacturonic acid, D-mannose, D-psicose, D-ribose, D-tagatose, D-xylose, gentiobiose, lactulose, L-arabinose, L-fucose, Lrhamnose, palatinose and turanose. CMB agar plates lacking glucose but containing casein $(2 \cdot 5 \%)$, gelatin $(0 \cdot 004 \%)$ or starch $(0.01 \%)$ were used to test for caseinase, gelatinase and amylase activities, respectively, using the methods described by Barrow \& Feltham (1993). Strain Kh10-101 ${ }^{\mathrm{T}}$ was capable of hydrolysing casein, gelatin and starch. Amylase production occurred at $\mathrm{pH} 7-10$ and $0-10 \%(\mathrm{w} / \mathrm{v})$ $\mathrm{NaCl}$ at an optimum of $5 \% \mathrm{NaCl}$ and $\mathrm{pH} 9$.

Catalase activity was positive as determined by dropping $\mathrm{H}_{2} \mathrm{O}_{2}$ on to colonies that developed on CMB agar plates. Aromatic compounds ( $p$-methylhydroxybenzoate, $p$-ethylhydroxybenzoate, $p$-propylbenzoate and sodium benzoate)

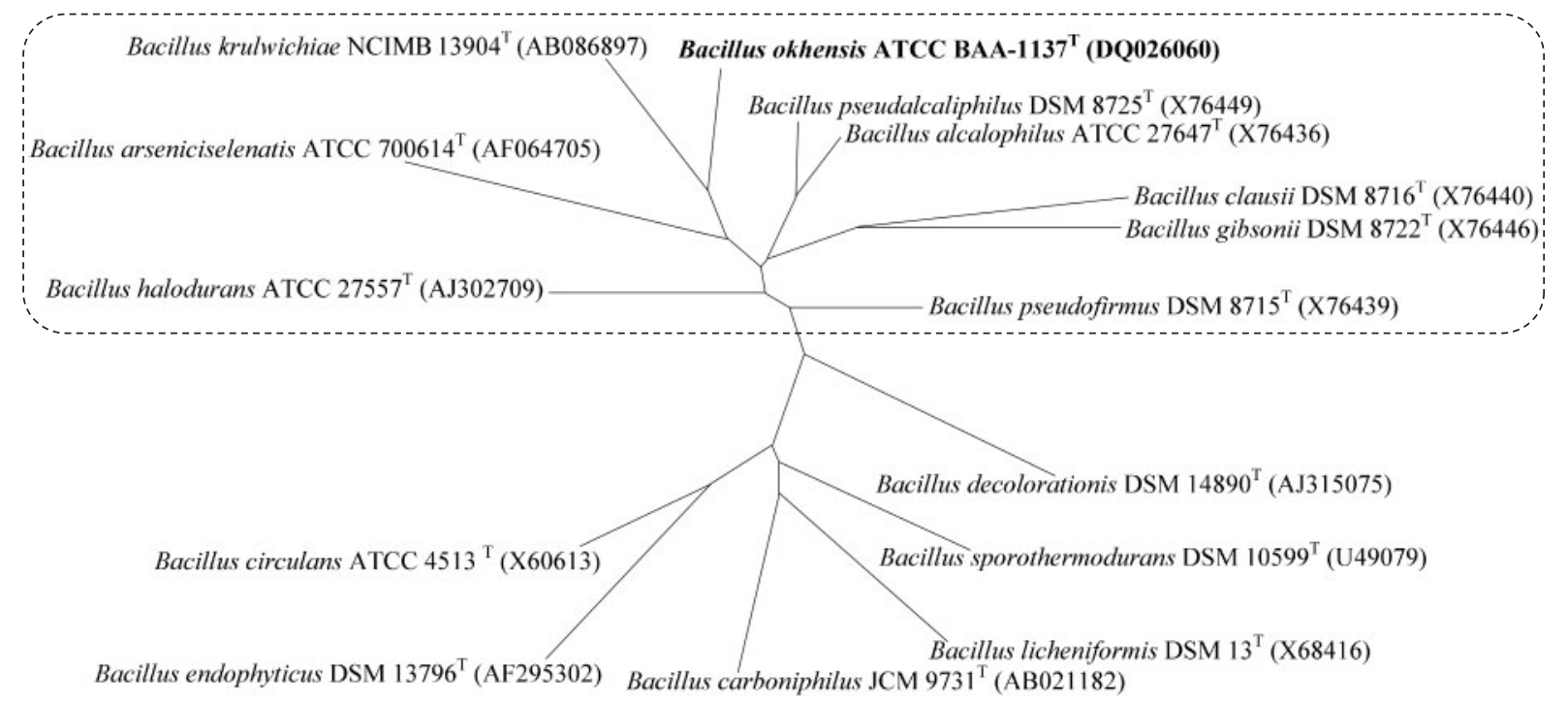

0.01

Fig. 1. Position of strain $\mathrm{Kh} 10-101^{\top}\left(=\mathrm{JCM} 13040^{\top}=\mathrm{ATCC}\right.$ BAA $\left.-1137^{\top}\right)$ within the radiation of members of the family Bacillaceae, phylum Firmicutes. Its close relationship to members of the sixth rRNA group represented by alkalitolerant and alkaliphilic members is shown as a box. Bar indicates 1 nucleotide substitution per 100 nucleotides. 
tested as carbon sources $(0.03 \%)$ in a medium $(\mathrm{pH} \mathrm{9.0)}$ containing (per $100 \mathrm{ml}$ ) $0.05 \mathrm{~g}$ peptone, $0.05 \mathrm{~g}$ yeast extract, $1 \mathrm{~g} \mathrm{KH}_{2} \mathrm{PO}_{4}$ and $5 \mathrm{~g} \mathrm{NaCl}$ were found not to be used. No growth was observed with Tween 40 or Tween 80 .

Genomic DNA was prepared using a modified method (Marmur \& Doty, 1961) in which achromopeptidase was added at a final concentration of $1 \mathrm{mg} \mathrm{ml}^{-1}$ for cell lysis and RNase was added at a final concentration of $20 \mu \mathrm{g} \mathrm{ml}^{-1}$ to digest RNA (Kanso \& Patel, 2003). The DNA was dissolved overnight at $4{ }^{\circ} \mathrm{C}$ in $0 \cdot 1 \times$ SSC to a concentration of $20 \mu \mathrm{g}$ $\mathrm{ml}^{-1}$. Escherichia coli genomic DNA prepared in the same manner was used as reference DNA. The DNA G+C content of strain $\mathrm{Kh} 10-101^{\mathrm{T}}$ was $41 \pm 1 \mathrm{~mol} \%$, determined by the thermal denaturation temperature $\left(T_{\mathrm{m}}\right)$ using a Cintra20 spectrophotometer (GBC Scientific Equipment).
The methods used for 16S rRNA gene amplification and sequencing have been reported previously (Andrews \& Patel, 1996). Partial sequences generated in this investigation were assembled and the consensus sequence was corrected manually for errors using BioEdit version 5.0.1 (Hall, 1999). The most closely related sequences against GenBank and Ribosomal Database Project II were identified using BLAST (Altschul et al., 1997) and the Sequence Match program (Maidak et al., 2001), extracted, aligned and manually adjusted according to the 16S rRNA secondary structure using BioEdit. Sequence uncertainties were omitted and phylogenetic reconstruction was achieved using TreeCon (Van de Peer \& De Wachter, 1994) in which pairwise evolutionary distances were computed from percentage similarities (Jukes \& Cantor, 1969) and phylogenetic trees were constructed from the evolutionary distances using

Table 1. Differential table comparing Bacillus okhensis sp. nov. Kh10-101 ${ }^{\top}$ and Bacillus krulwichiae AM31D ${ }^{\top}$

Both strains grew on D-fructose, D-galactose, D-glucose, glycerol and maltose. Both produced catalase and hydrolysed starch. The temperature growth range for both strains was $25-40^{\circ} \mathrm{C}$. Neither strain could grow on cellobiose, melibiose, myo-inositol, raffinose or sorbitol.

\begin{tabular}{|c|c|c|}
\hline Character & $\begin{array}{l}\text { Bacillus okhensis } \\
\qquad K \mathrm{Kh} 10-101^{T_{\star}}\end{array}$ & $\begin{array}{l}\text { Bacillus krulwichiae } \\
\qquad{\text { AM } 31 \mathrm{D}^{\mathrm{T}} \dagger}\end{array}$ \\
\hline Location isolated & Saltpan & Soil \\
\hline Morphology & $\operatorname{Rod}(0.6-0.8 \times 2-2.9 \mu \mathrm{m})$ & $\operatorname{Rod}(0.5-0.7 \times 1.5-2.6 \mu \mathrm{m})$ \\
\hline Motile & + & - \\
\hline Flagella & Terminal tuft of flagella & Peritrichous flagella \\
\hline Colony morphology & White round irregular edges & Colourless circular \\
\hline Spore formation & Not observed & Ellipsoidal \\
\hline $\mathrm{pH}$ growth range & pH 7-10 & $\mathrm{pH} 8-10$ \\
\hline $\mathrm{NaCl}$ growth range & $0-10 \%$ & $0-14 \%$ \\
\hline $\mathrm{G}+\mathrm{C}$ content $(\mathrm{mol} \%)$ & $41 \pm 1$ & $40 \cdot 6-41 \cdot 5$ \\
\hline Nitrate reduction & - & + \\
\hline Anaerobic growth & - & + \\
\hline \multicolumn{3}{|l|}{ Hydrolysis of: } \\
\hline Gelatin & + & Variable \\
\hline Casein & + & Variable \\
\hline Tween 40 & - & + \\
\hline Tween 80 & - & + \\
\hline \multicolumn{3}{|l|}{ Utilization of: } \\
\hline D-Mannose & + & - \\
\hline L-Rhamnose & + & - \\
\hline Lactose & + & - \\
\hline D-Xylose & - & + \\
\hline Mannitol & - & + \\
\hline Sucrose & - & + \\
\hline Trehalose & - & + \\
\hline Aromatic compounds $\ddagger$ & $-{ }^{\star}$ & + \\
\hline Benzoic acid & $-{ }^{\star}$ & + \\
\hline
\end{tabular}

*This study.

$\dagger$ Yumoto et al. (2003).

$\ddagger$ The aromatic compounds used are indicated in the main text. 
the neighbour-joining method (Saitou \& Nei, 1987). Tree topology was re-examined by the bootstrap method of resampling (Felsenstein, 1985) using 1000 bootstraps. BLAST results indicated a $96 \%$ similarity to the sixth $16 \mathrm{~S}$ rRNA group represented by the cluster of haloalkaliphilic and alkalitolerant members of the genus Bacillus and other related bacteria with the closest relative being Bacillus krulwichiae (96\% similarity) (Fig. 1). In addition to the phylogenetic distance separating strain $\mathrm{Kh} 10-101^{\mathrm{T}}$ and B. krulwichiae, a great number of phenotypic differences also suggest that strain $\mathrm{Kh} 10-101^{\mathrm{T}}$ is a different species (Table 1). For example, strain Kh10-101 ${ }^{\mathrm{T}}$ did not utilize Tween 40, Tween 80 , aromatic compounds or a range of carbohydrates (mannitol, trehalose and sucrose) but $B$. krulwichiae did. Also, strain Kh10-101 ${ }^{\mathrm{T}}$ used lactose, L-rhamnose and D-mannose but B. krulwichiae did not. Strain $\mathrm{Kh} 10-101^{\mathrm{T}}$ was a halotolerant alkaliphile and grew at neutral $\mathrm{pH}$ and with $\mathrm{NaCl}$ concentrations of up to $10 \%$ whereas B. krulwichiae was a halotolerant obligate alkaliphile which grew with $\mathrm{NaCl}$ concentrations of up to $14 \%$.

The DNA G+C content of strain Kh10-101 ${ }^{\mathrm{T}}$ was $41 \pm$ $1 \mathrm{~mol} \%$ and is similar to that for B. krulwichiae. Based on the phylogeny and phenotypic differences, we propose to designate strain Kh10-101 ${ }^{\mathrm{T}}$ a new species of Bacillus, Bacillus okhensis sp. nov.

\section{Description of Bacillus okhensis sp. nov.}

Bacillus okhensis (ok.hen'sis. N.L. masc. adj. okhensis pertaining to Port Okha, a port of the Dwarka region in India, where the type strain was isolated).

Cells are Gram-positive rods $(0 \cdot 6-0 \cdot 8 \times 2-3 \mu \mathrm{m})$ with a subterminal flagella tuft allowing vigorous forward propulsion. Spores are not observed and cells are sensitive to heat. Colonies are round and creamish with irregular edges. Growth occurs at $\mathrm{pH} 7-10$ and $0-10 \%(w / v) ~ \mathrm{NaCl}$. Grows optimally with $5 \% \mathrm{NaCl}$ ( $\mathrm{NaCl}$ growth range $0-10 \%$ ). Sensitive to lincomycin, meticillin, cefuroxime and cephalexin but resistant to gentamicin, tetracycline and cotrimazine. Utilizes 3-methyl glucose, D-fructose, D-fructose 6-phosphate, D-galactose, D-glucose, D-galacturonic acid, D-mannose, D-psicose, D-ribose, D-tagatose, D-xylose, gentiobiose, lactulose, L-arabinose, L-fucose, L-rhamnose, palatinose and turanose but not Tween 40 or 80 , glycerol, mannitol, sucrose, adenosine or dextrin. Hydrolyses casein, starch and gelatin, produces catalase and can not reduce nitrate. The DNA G $+\mathrm{C}$ content is $41 \cdot 6 \pm 1 \mathrm{~mol} \%$.

The type strain, Kh10-101 ${ }^{\mathrm{T}}$ ( = JCM $13040^{\mathrm{T}}=$ ATCC BAA$\left.1137^{\mathrm{T}}\right)$, was isolated from an Indian saltpan.

\section{References}

Altschul, S. F., Madden, T. L., Schäffer, A. A., Zhang, J., Zhang, Z., Miller, W. \& Lipman, D. J. (1997). Gapped BLAST and PSI-BLAST: a new generation of protein database search programs. Nucleic Acids Res 25, 3389-3402.
Amoozegar, M. A., Malekzadeh, F., Malik, K. A., Schumann, P. \& Sproer, C. (2003). Halobacillus karajensis sp. nov., a novel moderate halophile. Int J Syst Evol Microbiol 53, 1059-1063.

Andrews, K. \& Patel, B. K. C. (1996). Fervidobacterium gondwanense sp. nov., a new thermophilic anaerobic bacterium isolated from nonvolcanically heated geothermal waters of the Great Artesian Basin of Australia. Int J Syst Bacteriol 46, 265-269.

Barrow, G. I. \& Feltham, R. K. A. (editors) (1993). Cowan and Steel's Manual for the Identification of Medical Bacteria, 3rd edn. Cambridge: Cambridge University Press.

Demirjian, D. C., Morís-Varas, F. \& Cassidy, C. S. (2001). Enzymes from extremophiles. Curr Opin Chem Biol 5, 144-151.

Duckworth, A. W., Grant, W. D., Jones, B. E. \& Steenbergen, R. V. (1996). Phylogenetic diversity of soda lake alkaliphiles. FEMS Microbiol Ecol 19, 181-191.

Felsenstein, J. (1985). Confidence limits on phylogenies: an approach using the bootstrap. Evolution 39, 783-791.

Hall, T. (1999). BioEdit: biological sequence alignment editor for Win95/98/NT/2K/XP. Nucleic Acids Symp Ser 41, 95-98.

Jones, B. E., Grant, W. D., Duckworth, A. W. \& Owenson, G. G. (1998). Microbial diversity of soda lakes. Extremophiles 2, 191-200.

Jukes, T. H. \& Cantor, C. R. (1969). Evolution of protein molecules. In Mammalian Protein Metabolism, pp. 21-132. Edited by H. N. Munro. New York: Academic Press.

Kanso, S. \& Patel, B. (2003). Microvirga subterranea gen. nov., sp. nov., a moderate thermophile from a deep subsurface Australian thermal aquifer. Int J Syst Evol Microbiol 53, 401-406.

Maidak, B. L., Cole, J. R., Lilburn, T. G. \& 7 other authors (2001). The RDP-II (Ribosomal Database Project). Nucleic Acids Res 29, 173-174.

Margesin, R. \& Schinner, F. (2001). Potential of halotolerant and halophilic microorganisms for biotechnology. Extremophiles 5, 73-83.

Marmur, J. \& Doty, P. (1961). Thermal renaturation of DNA. J Mol Biol 3, 585-594.

Munoz, J. A., Perez-Esteban, B., Esteban, M., de la Escalera, S., Gomez, M. A., Martinez-Toledo, M. V. \& Gonzalez-Lopez, J. (2001). Growth of moderately halophilic bacteria isolated from sea water using phenol as the sole carbon source. Folia Microbiol (Praha) 46, 297-302.

Nielsen, P., Rainey, F. A., Ottrup, H., Priest, F. G. \& Fritze, D. (1994). Comparative 16S rDNA sequence analysis of some alkaliphilic bacilli and the establishment of a sixth rRNA group within the genus Bacillus. FEMS Microbiol Lett 117, 61-65.

Neilsen, P., Fritze, D. \& Priest, F. G. (1995). Phenetic diversity of alkaliphilic Bacillus strains: proposal for nine new species. Microbiology 141, 1745-1761.

Pikuta, E., Hoover, R. B., Bej, A. K., Marsic, D., Detkova, E. N., Whitman, W. B. \& Krader, P. (2003). Tindallia californiensis sp. nov., a new anaerobic, haloalkaliphilic, spore-forming acetogen isolated from Mono Lake in California. Extremophiles 7, 327-334.

Rees, H. C., Grant, W. D., Jones, B. E. \& Heaphy, S. (2004). Diversity of Kenyan soda lake alkaliphiles assessed by molecular methods. Extremophiles 8, 63-71.

Saitou, N. \& Nei, M. (1987). The neighbor-joining method: a new method for reconstructing phylogenetic trees. Mol Biol Evol 4, 406-425.

Suzuki, M. T., Rappe, M. S., Haimberger, Z. W., Winfield, H., Adair, N., Strobel, J. \& Giovannoni, S. J. (1997). Bacterial diversity among small-subunit rRNA gene clones and cellular isolates from the same sea water sample. Appl Environ Microbiol 63, 983-989. 
Van de Peer, Y. \& De Wachter, R. (1994). TREECON for Windows: a software package for the construction and drawing of evolutionary trees for the Microsoft Windows environment. Comput Applic Biosci 10, 569-570.
Yumoto, I., Yamaga, S., Sogabe, Y., Nadasaka, Y., Matsuyama, H., Nakajima, K. \& Suemori, A. (2003). Bacillus krulwichiae sp. nov., a halotolerant obligate alkaliphile that utilizes benzoate and $\mathrm{m}$ hydroxybenzoate. Int J Syst Evol Microbiol 53, 1531-1536. 